УДК 811.163.41'373

https://doi.org/10.18485/msc50_vuk_trsic.2021.ch20

\author{
Славко Вукомановић
}

\title{
ТУМАЧЕЊЕ РЕЧИ У ВУКОВОМ СРПСКОМ РЈЕЧНИКУ ОД 1852. ГОДИНЕ
}

Године 1818. Вук је, као што је познато, штампао свој први Српски рјечник. У том речнику су биле наштампане оне речи које је Вук, како сам вели, „донео амо (у Беч-С. В.) у глави”, па их је после писао како их се „могао опомињати”. Знатно касније, године 1852, појавио се опет у Бечу, под истим насловом Караџићев други речник.

Иако је наслов оба ова Вукова речника исти, већ на први поглед је лако уочити да су то два засебна лексикографска дела. У расправи $O B y$ ковим српским рјечницима (в. Кюижевност и језик, Беорад, 1975, св. I. Стр. 53-59) указао сам, у једном кратком осврту на ова два Вукова речника, да међу њима, поред заједничке концепцијске основе, постоје и знатне разлике, нарочито у лексичком фонду, прозодијским елементима, тумачењу речи и Вуковом језику. Ти се речници нарочито разликују по лексичком фонду. Први Караџићев речник садрћи углавном лексику његовог родног говора, пропуштену кроз Вуково језичко осећање. То је, у ствари, велика збирка речи једног нашег штокавског говора с почетка прошлог века, када још није била „модерна цивилизација унела у Вуков тршићки говор безбројне нове слојве, туђица и неологизама" (П. Ивић, О Вуковом Рјечнику из 1818. године, Сабрана дела В. Караџића, књ. 2, Београд 1964).

У другом речнику, који се појавио тридесет три године после првог Караџићевог речника, готово половина речи је штампана тада први пут. Речи за тај речник Вук је купио „по различнијем крајевима народа нашега и овога посла ради путовао је ... у Хрватску, Далмацију, Дубровник, Боку и Црну Гору" (Српски рјечник, Беч, 1852, предговор). Док је прикупљао грађу за свој други речник Вук је имао уза се и мрежу сарадника из различитих крајева простране српскохрватске језичке територије. Вуку су скупљали и слали речи: Адам Драгосављевић, Аврам Панић, Вук Поповић и Вук Врчевић. 
Када је штампао свој други Српски рјечник Караџић је имао иза себе готово четири деценије плодног филолошког рада. У то време он је био стекао детаљан увид у фонетске, граматичке и лексичке особености многих наших народних говора. У том речнику дошло је зато до потпуног изражаја, уз Вукову стваралачку интуицију, и његово продубљено филолошко знање и урођена акрибичност у скупљању и обради језичке грађе.

Од појаве Караџићевог другог Српског рјечника прошло је више од сто двадесет година. У том међувремену то дело је доживело - ако рачунамо и најновија фототипска издања „Нолита” у оквиру едиције изабраних дела Вука Стеф. Караџића - шест издања.

Природно је, свакако, што је у овом доста дугом временском периоду Вуков Српски рјечник од 1852. године пажљиво проучаван од стране наших најистакнутијих филолога и лингвиста. Запажен допринос проучавању овог Караџићевог речника дали су приређивачи државног издања од 1898. године П. П. Ђорђевић и Љ. Стојановић. О другом Вуковом речнику има доста драгоцених података и теоријских уопштавања у монографији Љ. Стојановића Живот и рад Вука Стеб. Карачића (Београд-Земун, 1924, стр. 653-665) и у књизи А. Белића Вукова борба за народни и кюижевни језик (Београд, 1948, стр. 161-170).

Али иако је за ових последњих сто и више година Вуков Сриски рјечник од 1852. године доста проучаван, ипак он све до данас није довољно испитан. Можемо чак рећи да нека основна питања која се тичу његовог лексичког фонда нису још добила праву научну верификацију и обраду. Испитивачи су, на пример, поодавно, констатовали да Рјечник садржи око 47.000 речи. Познато је, међутим, да је број лексема у том речнику знатно мањи, јер су у коначну цифру урачунате и многе речи које су фонетски дублети исте лексеме. Тако, на пример, лексема дјед појављује се у Рјечнику још у три различите фонетске варијанте: дјед, дед и дид. На сличан начин су у Рјечнику распоређене и обрађене и речи које имају глас $x$ (упореди, на пример, ајдук и хајдyк, ухо и уво и сл.). Ове и друге фонетске дублете Вук је уносио у свој речник зато што је тежио да у њему буде равноправно заступљена народна лексика из различитих крајева. Сва наша наречја су у Рјечнику у том погледу потпуно једнако представљена. Таква обрада речи механички је знатно повећавала фонд оних речи иза којих није стајало никакво самостално значење. Да је и сам Вук био свестан да је такав начин презентирања речи доста неприкладан, види се из следеће његове опаске:

„Ако кад Срби у писању књига приме једно макар које од својијех нарјечија, онда у рјечницима не ће ни требати ријечи по 
свакоме нарјечију писати за себе, него само по ономе којијем се књиге успишу, макар назначивши код сваке ријечи како се говори по другијем нарјечијима ... Али за сад док је још главна брига и потреба да познамо свој народни језик по свијем крајевима, мислим да је ваљало писати све овако као што сам ја у овој књизи писао” (Предговор Српском рјечнику од 1852. године).

У једном свеобухватном, систематском испитивању овог Вуковог речника биће неопходно прецизно утврдити тачан број речи, јер, као што се види, досадашње одређивање лексичког фонда у Рјечнику било је сувише механичко и непрецизно.

У проучавањима Караџићевог Српског рјечника од 1852. године остало је готово потпуно необрађено питање тумачења речи. Ту се није отишло даље од начелних констатација да је фразеологија у Рјечнику доста сиромашна и да је за око 6600 речи наведено место или шира област из које су узете те речи.

Данас када су се лингвистика и лексикографија као научне дисциплине у свету и у нас толико развиле и обогатиле нових сазнањима, целовито проучавање Вуковог Српског рјечника од 1852. године у једној ситентичкој студији неодложна је потреба и дуг према оснивачу наше националне науке о језику. Такво систематско испитивање Караџићева Српског рјечника било би, разуме се, непотпуно без детаљног увида у тумачењу речи. Али у једном аналитичком приступу обради ове теме треба, свакако, одвојити лингвистичка објашњења (прозодијске, фонетско-фонолошке и граматичке елементе) од семантичког тумачења речи.

Начело бисмо могли рећи да се Вукова фонолошко-прозодијска и граматичка одређивања речи углавном не разликују од устаљених принципа који се и данас примењују у нашој лексикографији. У речима су дати, најпре, прозодијски елементи, са карактеристичном новоштокавском политонијом и релевантним акценатским променама у парадигми. Тај новоштокавски четвороакценатски систем у овом Караџићевом речнику спроведен је доследно и од њега Вук не одступа чак ни у оним речима уз које је означено да се употребљавају у нашим старијим штокавским говорима за које знамо да у погледу акцентуације знатније одступају од новоштокавског четвороакценатског система. Поред бележења акцента, уз речи су наведене граматичке ознаке као што су: категорија речи, граматички род, затим неке морфолошке категорије сл. У Рјечнику су увек дате ознаке и за тзв. именице субјективне оцене (аугментативи, пејоративи, хипокористици). Ваља истаћи да су уз велики број речи наведене и регионалне ознаке места или краја у којима се оне говоре. Уз известан 
број речи дате су стилске ознаке које одређују сферу њихове употребе (стајаће ријечи, у песми, у загонеци и сл.).

Насупрот овој доста великој систематичности и једнообразности лингвистичко-граматичког одређивања речи, у Караџићевом Српском рјечнику постоји велико шаренило у лексичком (семантичком) тумачењу речи. Ту, прво, има речи чије значење уопште није протумачено. То су ове речи: гла̀дибрк, т., глу̀хара, f., гу̀гутка, f., гујбиврећa, f., гури́кало т., за̀ворнница, f., коноптаิк, m., кӱмодраิж, f., льу̀тич, т., мура́ја, f., по̀тквасница, f., ра̀ниิк, рани́ка, m., та̀мничаิрка, f., у́калица, f., щва́тьа, m., шѝка$p a, f .$, шкаю. Сам Вук је у Предговору објаснио да су то заправо оне речи уз које он, кад их је први пут чуо, није записао значење, мислећи да га неће заборавити, а после се тога значења није могао „опоменути”. Таких речи уз које се не наводи никакво објашњење има у Рјечнику врло мало.

Уз све друге речи дато је тумачење њихова значења. У том објашњавању појединих речи има, међуим, толико неуједначености и стога изгледа да је било каква класификација која би се заснивала на заједничким принципима готово немогућа.

Да би се све те недоследности у тумачењу речи могле јасније видеи, ми смо, полазећи од ове врло хетерогене речничке грађе, поједине речи које су истоветно протумачене груписали у веће целине.

У једној таквој подели најпре, дакако, ваља издвојити оне речи уз које се не даје никакво тумачење, осим што се оне упућују на неку другу, семантички истоветну или сродну реч чије је значење протумачено. У Рјечнику то изгледао овако:

ӒБЕР, m. vide хабер;

Мли́КО, n. (зап.) vide млијеко;

ЛЕ̂ВО (ист.) vide лијево.

Речи на чије се значење упућују ове речи Вук је протумачио овако:

ХӒБЕР, m. 1) Nachricht, nuncius, cf., глас:

Синоћ мени кара хабер дође,

Кара хабер, а у кара доба

2) нема (за то) ни хабера, т.j. није му ни бриге:

А за кулу ни хабера нема;

МЛИЈЕКО, n. (јуз.) die Milch, lac. 2) род по млијеку, т.j. по женској лози (а кад је по мушкој лози, онда се каже по крви);

лИЈЕВО (јуж.) links, leava (parte). 
У наведеним примерима, као што се види, у питању су фонетски дублети, тј. исте лексеме с различитим регионалним, дијалекатским изговором. То упућивање на одговарајући дублет јавља се редовно код речи које имају глас $x$ и различите рефлексе старог јата.

У Српском рјечнику има, међутим, и доста речи на које се упућује значење друге речи које нису фонетски дублети, већ засебне речи са истим или сродним значењем (синоними). Ту, на пример, долазе лексеме типа: млӥн-водѐница, млиิво-брӓшно-му́ка, муррва-дйд, мйкте-бада̀ваิ, ádem-ӧбичај, ӓла-ажда̀ха и сл.

За разлику од упућивања на фонетске дублете, које се обично врши помоћy vide, у овом другом случају када су у питању речи-синоними, корелација између тих речи успоставља се на неколико начина. Најједноставнији начин је, свакако, када се, исто као и код фонетских дублета, иза речи која се упућује ставља само vide или cf. Такво упућивање имамо у примерима:

А́ДЕТ, m. vide обичај;

МУ̀CTÂЋ, мустаћа, $\mathrm{m}$. vide брк;

МУ̀РУ, сf. шуру муру и сл.

Доста је, међутим, чест случај да се реч која се упућује на неки синоним само фразеолошки потврди као у примерима:

АิЛ, а́ла, m. vide биједа, напаст: ал те нашао! Но да видиш ала и белаја.

Понекад се за реч која се упућује на синоним даје цело мало енциклопедијско објашњење (обично оно шта се у народу о томе мисли и приповеда), а затим се наводи фразеологија. Такав случај имамо у примерима типа:

ӒЛА, f. vide аждаха: За алу се мисли да има од аждахе особиту духовну силу те лети и води облаке и град наводи на љетину. За змаја пак мисле да је као огњевит јунак, од којега у лећењу огањ одскаче и свијетли. Ало несита! Бори се као ала берићетом; А кад ала алу појахала.

Из ових примера у којима се поједине речи упућују на своје синониме јасно се види да се Вук ту није држао неких крутих, једнобразних принципа у објашњавању значења тих речи. Те једнообразности још је мање када се тумаче друге речи које се не налазе у поменутој синонимској корелацији. У тумачењу значења тих речи у Рјечнику има пуно не- 
склада и произвољности. Ту целокупну грађу можемо, ради боље прегледности, сврстати у неколико група.

Најмање компликовани начин тумачења речи јесте, свакако, када се поред неке речи наводи само кратко објашњење њеног значења на нашем језику. То имамо у примерима типа:

ЂӒКОВИЦА, f. варош у Метохији;

ПРЕેКРМАК, прекрмка, т. мушко јуне од године дана, од прилике као озимче;

АБОेНОС, т. дрво што у води отврдне (уабоноси се) као камен;

ГОेРЧИЛЕ, m. мушки надимак (тако највише прозову онога који се роди у планини код стоке)

ВӒИЛОВИЦА, f. манастир код Дунава близу Панчева;

ВУ̀ЦИњЕ, n. некако мјесто у јужном приморју;

ВРА́ЧЕВСКА МОेЛИТВА, f. (у Боци) некако молитва која се чита болесницима.

ӦБРิВКА, f. 1) двоструки конац на који се ните нити, т.j. који се провуче кроз велику иглу па се преко ње нити. Ако обрвка пукне, онда се сав нит оспе. 2) замка се начини око обрвке на коталцу, и та замка зове се обрвка на коталцу. 3) онај конац којим се брда увезују.

У другу групу иду примери у којима се поред кратког тумачења речи на српскохрватском језику наводи и фразеологија, као што је случај у следећим примерима:

БЁДРИНИЦА, f. у пјесми сабља што уз бедру стоји:

Повадише сабље бедринице;

PÂBНÔ, n. планина у Херцеговини:

Око њег'су велике планине:

Једно Равно а друго Чемерно.

Докл дођоше на Равно планину;

ПИРЙТОР, m. у Херцеговини зидине од старога градића, за који се пјева и приповиједа да је у њему сједио војвода Момчило, ујак Марка Краљевића, и да га је онђе убио краљ Вукашин;

Те је шаље на Херцеговину Бијеломе граду Пирлитору. Кад Момчило под Пирлитор дође;

ПЁТАР, тра, m. (у Ц. г.) горе под кровом у сваке зграде, гдје нема тавана од дасака, него је н. п. од љеса (доље је под, више пода петар, а под подом коноба, а у Брдима изба): Ђе је баба Руга? Ето је у кош на петар; 
ПЀТРОВО СУНЦЕ, п. т. ј. П е т р о в с ко, љетно:

Бачили их на Петрово сунще;

У примерима типа:

АВАНЙЦА, f.: Долетиће кобац аваница;

Одвести ће сјеницу дјевојку;

ПАЛА̀НДАРА, f.. И ево му мреже паландара;

ЗА́ПУС: И то Влаше запус учинило;

ВӰЧЕВО, п.: Од крнова до малог Вучева;

ЗӒРАВАิЊЕ, n.: Туна има село Зараване

дата је, као што се види, само фразеолошка потврда значења, без икаквог другог објашњења и дефиниције.

У оба Вукова српска рјечника, као што је познато, значење већине речи протумачено је на немачком и латинском језику. У свом првом ОБЯВЛЕНИЮ О СЕРСПКОМЕ РъЧНИКУ, штампаном у Новинама српским године 1816, Вук истиче да је свакој речи „приложио ... равнозначеће НЂмачке ръчи”. Међутим, у свом другом огласу о речнику (ВТОРО ОБЯВЛЕНИЮ О СЕ Р С П КО М Е С ЛО В А Р У), објављеном две године касније, 1818. године, у додатку Давидовићевим Новинама српским, Вук истиче да су речи у речнику „претолковане Нъмачкимъ и Латинскимъ езыкомъ”. Вук даље објашњава да је латински превод додат ради Француза и Енглеза и „осталые народа, кои не знаю Нъмачки”, као и ради „наши Србаля, кои уче Латински”.

Након ових начелних констатација о потреби оваквог „претолковања” речи немачким и латинским језиком, Караџић у овом другом ОБЯВЛЕНИЮ још једном детаљније објашњава зашто је баш узео немачки и латински језик. То Вук образлаже овако:

„Нїе ова кньига нужна и потребна само Списательима и кньижевницима Србскымъ, и иностранцыма, који су ради Србски учити, него особито и онымъ Србльима, кои уче, или кои су ради учити, Нъмачки или Латински: колика ће у томъ быти помоћъ Србльину, кадъ онъ сваку свою ръчъ, докъ отвори кныгу, може знати како се зове НЪмачки и Латински! А ова су два езыка нужна Србльима, не само оныма, кои живе у Нъмачкомъ Царству и желе у Нъммачку службу ступити, него и онымъ свима, кои желе быти учени люди у данашнъмъ свъту: зашто се на тимъ езыцыма налазе найлЂпше 
кньиге одъ наука, кое е већъ познато Руссима и Грцыма, и свима осталымъ народима".

Из овог Караџићевог образложења јасно се види да се он највише руководио практичним, образовно-педагошким разлозима када је решио да још у свом првом Сриском рјечнику речи тумачи немачким и латинским језиком, који су у Вуково време у школском образовном систему, науци и култури играли велику улогу. Тог свог начела Вук се, разуме се, држао и касније у другом Српском рјечнику, само што му је сада, уместо преминулог Копитара, речи преводио на латински и немачки језик Ђуро Даничић.

Али и овде, приликом тумачења речи помоћу немачког и латинског језика, у Српском рјечнику од 1852. године нема потребне систематичности и доследности. Велик број речи је протумачен тако што је дат само немачки и латински превод, без икакве фразеологије. То имамо у примерима типа:

БӦГОЈЕ, m. ein mannsname, nomen viri;

ГОЛУ்БИњА̂К, m. der Taubenschlag, columbarium;

ПРЁКСИНОิ, , vorgestern Abends, ante duos dies vesperi;

ПРЕКРОेЈИТИ, прекројим, v. pf. anders zuschneiden, seco ad aliam formulam;

ПРЁКЛАิНИิ, vor zwei Jahren, ante duos annos, ante biennium;

ПРЕГЛЕ́ДАТИ, прегледам, v. impf. 1) übersehen, perlustro. 2) nach dem Muster machen, facio ad exmplum;

ПРЕБАЦЙВАТИ, бацујем, v. impf. 1) hinüberwerfen, trajicio. 1) überwerfen, trajicio. 3) vorwerfen, exprobro, objicio.

У примерима као што су:

БЕСПОेСЛЕН, a, o, geschäftslos, otiosus: Беспослен поп и јариће крсти;

БЁСПОСЛИЦА, f. die Muse, otium: отићи ћу гдјегод на бесnослици. 2) die Tändelei, nugae: прођи се беспослище; то је беспослица. 3) der Müssiggänger, Tändler, otiator, homo nugax: иди беспослиио једна;

БЁРА̂Т, берата, m. ein Diplom, diploma: Док се лисици проуче берати, оде кожа на пазар;

ДИЈЁВАТИ, дијевам, v. imprf. (јуж.) thun, pono, colloco: Куда дијеваш ти толике новце? 
уз немачки и латински превод дате су, као што се види, и фразеолошке потврде за поједина значења.

За неке се речи прво наведе значење на српскохрватском језику, а затим следи немачки и латински превод. Такав случај имамо у примерима типа:

JÊTPBA, f. жене двојице браће јетрве су једна другој, die Schwagerin, leviri uxor;

JЁЧМАЧА, f. т. ј. крушка. eine Art Birn, pyri genus (што доспијева кад и јечам);

ЈУ́РНУТИ, јурнем, v. impf. као ударити, навалити у један пут, angreifen, aggredior;

JÀCТРОКА, f. (у Грбљу) име овци, ein Schafsname, nomen ovi indi solitum;

JАСТРЕ́БАЦ, репца, m. планина у Србији иза Крушевца, ein Berg in Serbien, mons Serbiae.

Доста су ретки примери у којима се поред објашњења значења на српскохрватском, немачком и латинском језику наводи и одговарајућа фразеологија као потврда тога значења. Такво тумачење речи имамо у примерима типа:

АБЕેЊАิК, абењака, m. капа од абе, eine Mütse von Aba-Tuch, galerus e panno aba dicto: Ћелавој глави абенак капа;

ӒЛАТ, т. црвен коњ, der Fuchs (Pferd), equus rufus: На алату вас у чистом злату;

БА̀ЛОТА, f. (по југоз. кр.) пушчано зрно, Flintenkugel, glans: Мање од балоте, а теже од стара соли (угљен);

БӒЛЧАК, т. у сабље или мача оно гдје се држи руком, der Griff am Säbel, kapulus:

Крвава му сабља до балчака;

БӒЊСКА̂, f. adj. варош у Косову, eine Stadt in Косово, nomen urbis:

Од малене Бағскке крај Косова.

У овом другом Караџићевом речнику значење речи некада је протумачено тако што је, поред објашњења на српскохрватском језику, реч преведена само на немачки или латински језик као у примеру:

JÄСТРОГ, m. (у приморју) морски велики рак, locusta marina. 
Оваква тумачења речи у Рјечнику веома су ретка.

Посебну пажњу заслужују, свакако, она тумачења кад Вук даје једно, целовито, енциклопедијско објашњење појма који реч означава и све оно што се у народу о томе појму зна и приповеда. Ту су уз речи најчешће објашњени многи народни обичаји, историјски догађаји и наведене различите легенде, народна веровања, описане игре, ношње и сл. Илустрације ради указаћемо овде на неколика таква објашњења:

Лу̀ЧИН ДАิН, m. der Tag des heil. Lukas (den 18, Oktober), dies S. Lucae festus. У Херцеговини на некијем мјестима на Лучин дан подрани домаћин у тор те гледа како му стока лежи: ако је подавила ноге пода се, онда веле да ће бити зла зима и година, ако ли је ноге опружила, онда веле да ће бити добра и зима и година.

КУМОेВСКА̂ СЛӒМА, f. (на небу) die Milchstrase, via lactea. Срби приповиједају да је кум у кума украо бреме сламе, па како га је носио слама испадала и просипала се путем, онако Бог оставио на небу за вјечни спомен.

КОेРОНА, f. уврх Овчара више намастира Сретенија једна долина зове се мала Корона, а више ове долине један затаванак, на коме има и мали извор, велика Корона, а испод њих зове се Корунски до. Приповиједа се да су у стара времена, кад су овај намастир најприје хтјели градити, бацали круну у небо, да гледају на коме ће се мјесту уставити, па ондје да граде цркву; и од тога остало име Корона.

ДОेБЈЕГЛИЦА, f. (јуж.) дјевојка која добјегне (т.j. сама дође) за момка; то се догоди кад родитељи не даду дјевојци поћи за кога она хоће, а она не ће за кога је он и дају. То су понајвише рђаве дјевојке: јер поштена дјевојка, и од поштена рода, неће своје родитеље и браћу осрамотити. У Србији добјеглица дође управо момку у кућу, па је онда одведу у каву кућу момачком роду, те тамо стоји док се не вјенчајну, а у Сријему и у Бачкој дође поповој кући и ондје стоји док се не вјенчају.

Поред оваквих, релативно краћих, енциклопедијских тумачења која се уз речи наводе у овом Вуковом речнику има доста речи које су објашњењне знатно опширније. Ако, на пример, погледамо објашњења речи као што су: хајдук, школа, намастир, кмет, кнез, справа, спахија, отмица и сл., лако је запазити да су ту, у ствари, дате целе мале студије из историје, етнологије, социологије и сл. Из тих прозних састава и коментара види се колико је Вук био дубоко проникнуо у све видове народног живота и народних обичаја. И њега у Рјечнику нису занимале само народне речи, њихови граматички облици и значења, већ и све оно што у 
народу око тих речи живи, и што се приповеда. Речи су ту најчешће само повод да се о разгранатом и многоструком народном животу дају опсежна и аутентична сведочанства. Полазећи од ове Вукове речничке прозе, мислим да са правом можемо рећи да Српски рјечник од 1852. године није само једна драгоцена збирка народних речи, већ да је о у великој мери и једна мала енциклопедија народног живота, обичаја и веровања.

Када је још у првом речнику, по савету Копитаревом, почео да додаје уз речи ове прозне коментаре и објашњења, Вук је до последњег часа рада на свом другом Српском рјечнику настојао да и са те стране његов речник буде што потпунији и богатији. То се јасно види из његовог предговора другом Српском рјечнику у коме, поред општих напомена о принципима којих се држао у изради речника, стоји и ова важна белешка: „К ономе што је год ријечи крајин аказано о Крајини Неготинској од најстаријих људи у Крајини дознао и мени јавио, и то..." (следи опширан чланак, с многим појединостима, о купљењу пореза, баш кнезу и пандурима, локалним расправама и суђењима и сл.).

Вук је, као што се види, ову страну рада на Рјечнику сматрао веома важном, па је чак она објашњења која није стигао да унесе на одговарајућем месту у Рјечнику штампао накнадно у свом предговору у виду опширне белешке.

Оваквих мањих или већих коментара који се додају уз поједине речи у Рјечнику има доста. Поред историјске, социолошке, етнолошке грађе, која је, несумњиво, највише заступљена, у Рјечнику има и драгоцених података из географије, ономастике, дијалектологије, фолклора и сл. Познато је, например, да је управо Вук у овом свом речнку први констатовао да се у селу Доброти крај Котора изговара стари полугласник. Ево шта Вук уз реч Доброта о томе каже: „А језик им се од Црногорског највише разлике по томе што на онијем мјестима гдје је у староме Славенскоме $b$, у Рускоме $е$ или $o$, а у Српскоме $a$, не говоре никаквога чистога самогласна с лова, него као пола њега (да се не може разликовати које је) н.П. мъч, къд, чъст, почъст и т. д."

Саставни део тумачења речи чини, свакако, и фразеологија. Одавно је с правом речено да је фразеологија у Вуковом Рјечнику врло оскудна. Има много речи уз које се не наводе никакве фразеолошке потврде. Уз неке речи, опет, потврђено је само понеко значење. За једно значење најчешће се наводи по једна потврда, али има и доста примера у којима се за исто значење даје више потврда. Као потврда значења у Рјечнику се најчешће наводе стихови из народних песама, затим народне пословце, мудре изреке, загонетке, идиоми и сл. Понекад се, међутим, дају и потврде из свакодневног, разговорног језика. То имамо, на пример, у овим 
фразеолошким потврдама, које су у Рјечнику наведене уз одговарајуће речи: Легао покрај пећи на банак. Нешто сам аста. Он је аста. Ми смо се бахатили. Ја сам се с њим бахатао. Зарасло жито у траву. Зарастао пут. Зарасло село у шуму. Зар ти не знаш? Зар ће он доћи? Запрећи јаје у ватру нека се испече. Заошени мало тај крај греде.

Из целокупне досадашње анализе јасно се, међутим, види да се у тумачењу речи у Српском рјечнику Вук није држао никавих строгих лексикографских принципа. У Рјечнику има, као што смо видели, у том погледу пуно произвољности и недоследности. За већину речи дато је значење на српскохрватском, немачком и латинском језику. Поједине речи су, међутим, остале готово потпуно и необјашњене. За известан број речи наведена је само фразеологија, без икаквих других коментара и објашењења. На другој страни неке речи су објашењене много шире него што је уобичајено у лексикографским делима овога типа. Рекли смо већ да су то понекад целе мале студије из историје, етнологије, социологије, фолклора и сл. Има, међутим, у овом Караџићевом речнику више примера у којима су речи протумачене сасвим у складу са принципима и модерне лексикографије. Ту су, наиме дата сва значења појединих речи тумачења на српскохрватском, немачком и латинском језику и наведене су за свако значење фразеолошке потврде.

Логично је да се сада запитамо: зашто је Вук у тумачењу речи био тако недоследан? Откуда ту толико шаренила и произвољности који се крећу, као што смо видели, од минималне информације о речима па све до опширне расправе, данас уобичајене само у енциклопедијама?

Детаљан увид у ова питања данас, када су нам многе појединости око израде Рјечника готово сасвим непознате, није, разуме се, уопште могућ. До данас су остала нерасветљена чак и тако важна питања као што је Даничићев удео у изради Рјечника. Вук је у Предговору о томе лаконски рекао само ово: „Велика хвала Ђуру Даничићу, који се трудио око превођења ријечи на Њемачки и Латински језик и око поправљања и нагледања у штампању”. Више појединости о тој сарадњи на изради Вуковог Српског рјечника налази се у једном Даничићевом писму упућеном Ђорђу Натошевићу. У том писму, у коме је, као што ћемо видети, веома неповољно оцењен Рјечник, Даничић о Рјечнику и своме раду на Рјечнику каже ово: „Не ћу помињати шта је написано и додато за ове неколике године како му ја око рјечника помажем, и шта се и у пошљедњем коректурама додаје, него да речемо да сам све ја затекао, опет ће бити мало, врло мало за тридесет и неколике године дана! Мене - ја мислим да нико кривити не може што овај рјечник није бољи. Мој је посао управо био сам уредити га за штампу и у штампању старати се око њега, 
а највише могло би се рећи да ми је био посао од Вукове грађе (подвукао С.В.) начинити што се могло, па ни то не по својој вољи. И ја мислим да сам заиста учинио што се гот могло учинити за ово мало времена (за четири године дана, и то не радећи само то, него поред тога штампајући пословице и Ковчежић, пишући и штампајући Приповијетке из Старога и Новога Завјета и малу граматику, и друго којешта радећи). Моја је заслуга: што рјечник излази (како је да је) и то - мислим - не мала, јер ће рјечник овај проед све сиротиње своје и свију мана опет бити од велике користи за нашу књижевност" (Даничићев зборник, Београд-Љубљана, 1925, стр. 243).

Из овога Даничићевог казивања може се назрети како су се јавиле овако велике разлике у тумачењу појединих речи у овом Вуковом речнику. Истакли смо напред да Вукова намера није само била да у свој речник унесе све народне речи до којих је могао доћи и да се уз њих наведе значења, већ да уз поједине речи забележи и све оно што око тих речи у народу живи. Уз речи је, дакле, Вук додавао све оно што је о њима знао. Оно што није знао, или је знао недовољно, остало је непотпуно. Тако се једино може разумети зашто Вук, на пример, уз реч авајлија каже само „(у Уж. н.) некака јабука", а уз реч школа даје целу малу историјско-социолошку студију. За коначну физономију Рјечника од пресудног знача је, несумњиво, била грађа којом је Вук располагао. Тамо где је грађа била оскудна и речи су остале недовољно објашњене, без фразеолошке документације, а тамо пак где је грађа била богата и речи су објашњене шире, понекад знатно више него што је за једно овако лексикографско дело било потребно. Држећи се тог основног принципа у састављању Рјечника, Вук је неминовно морао нарушити унутрашње пропорције и лексикографску доследност у тумачењу речи.

Због веома хетерогене грађе коју садржи, Рјечник је знатно изгубио на лексикографској кохерентности. По лексикографској обради већине речи то је, у ствари, тројезични речник. Али по неким својим карактеристикама Вуков Српски рјечник садржи и елементе енциклопедијског лексикона и речника синонима. По лексичком фонду и граматичкој обради, међутим, то је речник новоштокавског дијалекта и његових основних наречја. А како је новоштокавски дијалекат (његови млађи говори) у прошлом веку узет за основицу нашег књижевног језика, јасно је да је велики део лексичког фонда Вуковог Рјечника постао саставни део књижевнојезичке лексике, па је по тим својим елементима Српски рјечник донекле и речник класичног српскохрватског књижевног језика Вукова времена.

Ако бисмо, дакле, хтели да мерилима модерне лексикографије, којој су познате десетине различитих врста речника, оценимо Вуков Српски 
рјечник, онда, нема никакве сумње, да бисмо морали рећи да је то један врло специфичан тројезични речник који садржи, у већој или мањој мери, и елементе речника синонима, дијалекатског речника, речника класичног књижевног језика, енциклопедијског лексикона и сл.

Овако хетерогена језичка грађа и врло специфичан начин њене обраде били су, вероватно, главни разлог што је веома педантни Ђуро Даничић, који је у свему тражио један строги граматички и језички систем, онако негативно оценио Вуков Српски рјечник. Даничић који је био превасходно систематизатор и кодификатор језичке грађе, први српски модерни филолог-граматичар, није могао, свакако, да се помири са тим да у један рјечник који садржи народну лексику из различитих крајева уђе и сва она друга фолклорна грађа која Вуковом Српском рјечнику даје, као што смо видели, специфичан карактер. Да је за Даничића највише спорна била Вукова, за граматичаре и уске језичек стручњаке мало необична, концепција речника, јасно се види из ове његове јетке примедбе на Вуков начин: „Из огласа Вукова видјећеш како он разумијева што је рјечник („u саме забаве ради” да га „чита сваки Србин и свака Српскиюа колико и каку другу књигу"). С овијем мислима рјечници се не пише" (Даничићев зборник, стр. 243).

Очигледно је, дакле, да је управо оне многобројне прозне додатке и коментаре, до којих је Вуку посебно било стално да се нађу у Рјечнику, Даничић сматрао чистим промашајем, јер по његовим строгим ускофилолошким мерилима у једном оваквом речнику та додатна грађа могла је бити само непотребно оптерећење и баласт.

Ако данас, са доста велике временске дистанце, анализирао ову Даничићеву врло оштру критику Вуковог рада на Српском рјечнику и његовој доста оригиналној концепцији, није тешко закључити да је Даничић само делимично био у праву. Целокупна наша анализа тумачења речи у овом Вуковом речнику јасно, мислим, показује да у томе има пуно пропуста и несистематичности, тако да тај речник и сада, после толиких Даничићевих интервенција и накнадне обраде, изгледа у великој мери као само делимично обогаћена збирка лексичке и друге сродне грађе за једно целовито лексикографско дело. Али, са друге стране, та је грађа толико богата и разноврсна и била би, свакако, велика штета да је Вук није обелоданио у Рјечнику. Захваљујући баш тој и таквој грађи Вуков Српски рјечник од 1852. године драгоцена је ризница података о најразличитијим странама народног живота, незаменљиви изговор грађе за историчаре, етнологе, социологе, дијалектологе и све оне које проучавају било коју страну народног живота и народног стваралаштва. 
Управо због овако широке и разнолике филолошке концепције, овај Караџићев Српски рјечник је, несумњиво, био, и остао све до данас, књига коју је могао да, „забаве ради, чита сваки Србин и свака Српкиња колико и каку другу књигу”. Да је то тако најбоље, свакако, показује чињеница што је то прозно штиво из Вукова Рјечника пре десетак година објавила, под мало необичним насловом (Расковник), београдска „Просвета” у својој елитној едицији „Бразде”, у којој се углавном публикују прозна и песничка дела најистакнутијих савремених југословенских писаца. Што је та књига, у чијем поднаслову стоји Проза из Рјечника, завредела да се данас, готово стотину и тридесет година после обелодањивања тих текстова, наиђе међу писцима нашим савременицима треба, свакако, захвалити томе што се онда, уз своју непролазну тематску актуалност, и сада чита са лакоћом и великим интересовањем.

Ако бисмо сада, на крају ових наших разматрања о Вуковом Сриском рјечнику, хтели да дамо једну сажету оцену, онда бисмо, парафразирајући Даничићево мишљење о Вуковом преводу Новога завјета, могли рећи да је то Караџићево дело, уз све осцилације и недоследности у тумачењу речи, круна његовог филолошког рада. Ту се заправо Вук појављује у исти мах и као акрибични верификатор и аналитичар разнородне филолошке грађе и као зрели стваралац синтетичар, који је до танчина ушао у све тајне филололошког рада.

* Рад је претходно објављен у зборнику Научни састанак слависта у Вукове дане, 5, 705-717. 